
ДЕРМАТОЛОГИЈИ

Констанса Лазаревић ${ }^{1}$

\title{
BALNEOTHERAPY AND CLIMATOTHERAPY IN DERMATOLOGY
}

Konstansa Lazarević

\section{Сажсетак}

Корисниефекти балнеотерапијеиклиматотерапије на дерматолошке болести коришћени су од давнина. Овај преглед ће се фокусирати на тренутне доказе о дејству балнеотерапије и климатолошке терапије на неке дерматолошке болести.

Клучне речи: балнеотерапија, климатотерапија, кожне болести.

\section{Summary}

The beneficial effects of balneotherapy and climatotherapy in the treatment of dermatologic diseases have been used since ancient times. This review will focus on the current evidence regarding the effects of balneotherapy and climatotherapy in some dermatological diseases.

Key words: balneotherapy, climatotherapy, dermatologic diseases.

\footnotetext{
${ }^{1}$ Доц. др Констанса Лазаревић, Департман за биомедицинске науке, Државни универзитет у Новом Пазару, Србија.
} 


\section{УВОД}

Б алнеоклиматологија је медицинска дисциплина која се бави изучавањем деловања природних физичких и хемијских чинилаца спољне средине на људски организам, и могућностима њихове примене у медицинске сврхе. Најчешће коришћени природни чиниоци су: минералне воде, пелоиди (лековита блата), парцијални притисак кисеоника, угљендиоксид, топлота и хладноћа, и хидростатски притисак. ${ }^{(1)}$

У лечењу кожних болести, балнеоклиматски чиниоци (минералне воде, пелоиди, сунчева светлост и др.) примењивани су још код старих Римљана, Грка и Египћана. Комбинацију биљних екстраката и излагање сунцу, стари Египћани (525. године п.н.е.) користили су за лечење витилига, а Клеопатра је помоћу глине неговала своју кожу.

Климатотерапија се примењивала у лечењу хроничних болести коже за време Хипократа (500. године п.н.е.), а у старом Риму бање са термалним минералним водама коришћене су за опоравак повређених војника. ${ }^{(2)}$ Иако је неко време примена балнеоклиматских чинилаца у лечењу многих болести напуштена, у XVI веку се са њеном применом поново започело. У то време, у Верони је отворено јавно купатило које се снабдевало водом богатом сумпором. Ово купатило се користило за лечење кожних болести, пре свега шуге. ${ }^{(3)}$

Примена балнеотерапије као важног медицинског третмана у лечењу кожних болести започела је поново тек 1800 . године, најпре у Европи, а затим у Сједињеним Америчким Државама. Популарност балнеотерапије је убрзо опала да би доживела препород током протекле четири деценије. ${ }^{(4)}$

Новија истраживања указују да је примена балнеоклиматских чинилаца често делотворнија у лечењу и очувању здравља коже у односу на примену фармаколошких средстава.

\section{ДЕРМАТОЛОШКА ОБОЉЕЫА И БАЛНЕОТЕРАПИЈА}

У савременој козметологији, минералне воде могу бити ефикасна замена или додатни састојак производа који се користи за лечење неких болести коже. Минералне воде могу се користити и као састојак производа за негу различитих типова коже. ${ }^{(5)}$

Због свог састава богатог минералима и ретких нежељених реакција током њихове примене, термалне воде се сматрају сигурним и успешним средством у дерматолошкој пракси.

Термалне воде - у природном облику или у козметичким производима, индиковане су у дерматологији за хидратацију коже, у превенцији старења коже, лечењу акни, розацее и других запаљенских дерматоза, као и након козметичких процедура као што су хемијски пилинг и ласер. Примена термалне воде у овим стањима смањује иритацију, пецкање, свраб, љуштење и црвенило коже. ${ }^{(6,7)}$

Дерматолошка обољења код којих се са великим успехом примењују балнеоклиматолошки чиниоци (минералне воде, пелоиди, хелиотерапија) јесу псоријаза и атопијски дерматитис.

У остала обољења коже код којих се примењује балнеотерапија спадају acne vulgarus, atopic dermatitis, alopecua areata, contact dermatitis, dyshidrotic dermatitis, eczema, granuloma annulare, ichthyosis vulgaris, lichen planus, lichen sclerosis and atrophicus, mycosis fungoides, necrobiosis lupoidica, palmoplantar keratosis, parapsoriasis, pityriasis rubra pilaris, pruritus, psoriasis, rosacea, scleroderma, sebopsoriasis, seborrhoic dermatitis, ulcer (chronica), urticaria pugmentosa, vitiligo u xerosis. ${ }^{(8)}$

Механизми помоћу којих балнеоклиматотерапија делује на широки спектар болести заснивају се на физиолошком, хемијском, термичком и механичком дејству балнеоклиматолошких чинилаца. 
Ефекти балнеотерапије зависе пре свега од хемијског и минералног састава воде, као и степена апсорпције минерала присутних у води. Различите болести захтевају различите концентрације одређених елемената да би се постигли оптимални терапијски резултати.

Сумпорне и сумпоровите минералне воде се одавнина користе у медицинске сврхе. Сумпор је познат по свом антиинфламаторном, антибактеријском и антифугалном дејству, те је јасно што се употреба минералних вода богатих сумпором препоручује у лечењу акни, инфекција улцера ноге, као и гљивичних инфекција коже (tinea versicolor, tinea corporus $u$ tinea capitus). ${ }^{(9)}$

Сумпор се добро апсорбује кроз кожу, изазива вазодилатацију, аналгезију, инхибицију имунолошког одговора, делује кератолитички и смањује десквамацију коже. ${ }^{(10)}$ Из тог разлога се сумпорне купке успешно користе у имуно-посредованим болестима коже: код псоријазе и атопијског дерматитиса. ${ }^{(8)}$

Тронедељна терапијска примена минералне воде и пелоида Пролом Бање показала је задовољавајуће терапијске резултате код пацијената оболелих од псоријазе, као и истовремена примена медикаментозне терапије и балнеотерапије код пацијената лечених од псоријазе у Русанда Бањи. ${ }^{(11,12)}$

Бање богате сулфидним минералним водама у Србији су Матарушка бања, Бања Ковиљача, Бања Врујци, Рибарска бања, а сулфатним минералним водама Брестовачка бања, Сијаринска бања, Рибарска бања, Бања Врдник и Врањска бања.

На Табели 1. приказан је биолошки ефекат неких минерала често присутних у термалним минералним водама на кожу. ${ }^{(13)}$

Табела 1. Биолошки ефекти / терапеутска примена неких минерала присутних у термалним водама.

\begin{tabular}{|c|l|l|}
\hline $\begin{array}{c}\text { Редни } \\
\text { број }\end{array}$ & \multicolumn{1}{|c|}{ Минерал } & \multicolumn{1}{|c|}{ Биолошки ефекти / терапеутска примена } \\
\hline 0 & \multicolumn{1}{|c|}{1} & \multicolumn{1}{|c|}{2} \\
\hline 1 & Алуминијум & Акутни дерматитис \\
\hline 2 & Арсеник & Псоријаза \\
\hline 3 & Бор & Обнављање ћелија, зарастање рана \\
\hline 4 & Калцијум & $\begin{array}{l}\text { Регулација раста епидермалних ћелија, антиинфламаторно } \\
\text { дејство }\end{array}$ \\
\hline 5 & Натријум-хлорид & $\begin{array}{l}\text { Хидратација слоја кератина у хиперкератотским } \\
\text { поремећајима }\end{array}$ \\
\hline 6 & Бакар & Антиоксиданс, опоравак кожне баријере \\
\hline 7 & Сумпор & Антинфламаторно, антибактеријско и антифугално дејство \\
\hline 8 & Магнезијум & Ћелијска обнова коже/дерматитис \\
\hline 9 & Манган & Обнављање ћелија, зарастање рана, опоравак кожне баријере \\
\hline 10 & Селен & $\begin{array}{l}\text { Антиоксидативно дејство, заштита од UVB зрачења / } \\
\text { себореични дерматитис, tіпеа vегsicolor }\end{array}$ \\
\hline 11 & Натријум & Обнова ћелија \\
\hline 12 & Цинк & $\begin{array}{l}\text { Антиоксиданс, ћелијски метаболизам, модулатор } \\
\text { инфламације }\end{array}$ \\
\hline
\end{tabular}


Термичко дејство балнеотерапијских чиниоца у највећој мери зависи од температуре воде. Термална стимулација коже побољшава циркулацију крви, лучење норепинефрина, кортизола и фактора раста и на тај начин и повећава исхрањеност коже, елиминацију штетних материја из коже и њену гипкост. ${ }^{(1)}$

Сумпоровите термалне минералне воде се у Француској већ више од 100 година користе у терапији хипертрофиране коже, ожиљка, црвенила и пруритуса, насталих као последица опекотина, али тек након хируршке фазе опоравка када су ране затворене. ${ }^{(14)}$

На кожу захваћену рефракторним атопијским дерматитисом могу утицати поједини параметри воде: $\mathrm{pH}$, тврдоћа воде, осмоларност и температура. ${ }^{(15)}$ У Јапану је купање у сумпоровитим термалним водама киселе $\mathrm{pH}$ вредности једна од опција у лечењу рефрактарног атопијског дерматитиса. За ове воде је познато да имају антибактеријски ефекат на Staphilococcus aureus, који често захвата кожу оболелих од атопијског дерматитиса. ${ }^{(16)}$

\section{ДЕРМАТОЛОШКА ОБОЉЕЫА И ПЕЛОИДОТЕРАПИЈА}

Пелоиди су геолошки створени продукти из неорганских и/или органских материја који могу да се користе за лечење у облику купања или облагања. Пелоиди се деле на природне и вештачке, а по пореклу могу бити органски и неоргански, и мешовити органско-неоргански. Пелоид се користи од давнина, пре 4.000 година Египћани су користили пелоид у лечењу опекотина.

Хемијски ефекат пелоида није довољно познат, али се сматра да он зависи од $\mathrm{pH}$ пелоида. Алкални пелоиди чине кожу пропустљивом за катјоне, а кисели за анјоне. Из пелоидне суспензије кроз кожу продиру сумпор, сумпорводоник, нека једињења гвожђа, витамини Ц и Д.(1)
Захваљујући својој апсорпцији и адсорпцијским капацитетима, неки пелоиди могу се користити у лечењу отока, едема и упале. Пелоиди који апсорбују нечистоћу, масноћу и токсине се користе у терапији упала коже, чирева, акни и себореичног дематитиса. Хуминске материје из органских пелоида имају својство апсорпције и из купки извлаче материје које је тело излучило и делују, сужавају поре и регулишу лучење лојних жлезди. ${ }^{(1)}$

Топлота из пелоида изазива ширење пора, појачан рад лојних жлезди и излучивање токсина, ${ }^{(17,18)}$ а има и аналгетско дејство.

Гомес и Силва наводе да сваки минерал из пелоида има неку своју улогу у метаболизаму коже: зарастање рана, апсорпција себума, хидратација, антисептичко дејство, и утиче на васкуларизацију и елиминацију токсина. ${ }^{(19)}$

Минерална блата са високим степеном рефракције блокирају дејство UVA и UVB сунчевих зрака и улазе у састав емулзија и пудера, ${ }^{(20,21)}$ штите кожу од оштећења насталог дејством UV зрака, и превенирају настанак малигних тумора коже.

И анализа улцињског пелоида је показала да овај пелоид садржи високу концентрацију различитих минерала, органских материја, као и да поседује одређена антимикробна својства. Захваљујући овим његовим особинама, његова примена у дерматологији и козметологији може допринети регенерацији и ревитализацији коже. Механички ефекат овог пелоида на кожу потиче од финих зрна пелоида која делују кератолитички и уклањају нечистоће са површине коже, ${ }^{(22)}$ а примењен у облику паковања има повољне ефекте код лечења розацее, акни и атопијског дерматитиса. ${ }^{(23)}$

Примена топлих паковања пелоида богатог сумпором нормализује $\mathrm{pH}$ нормалне, суве и себороичне коже и регулише лучење себума. ${ }^{(24)}$

У козметичкој индустрији неке врсте глина се користе за стабилизацију емулзија или суспензија и за модификовање реолошког понашања ових система. Оне, такође, 
играју важну улогу као адсорбенти или апсорбенти, не само у козметици, већ и код фармацеутских производа. ${ }^{(25)}$

\section{ДЕРМАТОЛОШКА ОБОЛЕЫА И КЛИМАТОТЕРАПИЈА}

Адаптивне реакције коже на метеоролошке и атмосферске климатске факторе развијају се јако брзо, али су пролазне и зависе од трајања изложености.

Већина адаптивних кожних процеса настаје као последица адаптације кардиоваскуларног, нервног, ендокриног, респираторног, дигестивног, и хематопоетског система. Адаптивне реакције, као што су тахикардија, тахипнеја, повећана синтеза хемоглобина, узрокују промене у циркулацији коже и повећавају респираторну активност коже. То су заправо адаптивне реакције саме коже.

Климатотерапија се примењује углавном код пацијената са алергијским дерматозама, као што су: атопијски дерматитис, хронична алергијска уртикарија и неуродерматитис. Третман хроничне неалергијске уртикарије климатотерапијом такође се показао као веома успешан. Велики успех је постигнут и у лечењу parapsoriasis placata и иницијалних облика микоза, као и благих и стабилизованих облика dermatitis herpetiformis Dihring и pemphigus. Често ce климатотерапија примењује у циљу постизања смањења терапијске дозе или потпуног прекида фармаколошке терапије у одређеном периоду. ${ }^{(26)}$

Атопијски екцем је једна од најстаријих и најважнијих индикација за примену климатотерапије. Клима којој се излажу оболели мора се карактерисати ниским садржајем аероалергена (прашине, полена и сл.) и загађивача ваздуха. Довољно висок атмосферски притисак хладног ваздуха, без присуства влаге у ваздуху, доводи до нормализације функције знојења и има антиинфламаторни и антипургативни ефекат. Осим тога, клима мора имати интензивно природно сунчево зрачење, које поред бактерицидних ефеката има и антиинфлама- торни и антипролиферативни имунолошки ефекат који се остварује директно на кожи.

Од климатских процедура у лечењу атопијског дерматитиса препоручују се хелиотерапија (терапијска изложеност сунцу у природним условима), боравак на свежем ваздуху (са телом заштићеним од хладног ваздуха), теренска терапија (планинарење (ерготерапија) у хладним условима), и таласотерапија (ефекат морске климе у комбинацији са купањем у мору).(27)

Хелиотерапија се нарочито показала ефикасном у лечењу пацијената са псоријазом и атопијским дерматитисом. ${ }^{(28)}$

Пацијенти оболели од витилига чине трећу највећу групу дерматолошких пацијената који посете Мртво море. Третман за витилиго се заснива на постепеном повећању излагања коже ултраљубичастим зрацима, који стимулишу меланоците на погођеним подручјима да нормално функционишу. Репигментација је обично спора и наставља се и после прекида терапије. ${ }^{(29)}$

\section{ДЕРМАТОЛОШКА ОБОЉЕЫА И ТЕРАПИЈА ПРИРОДНИМ ГАСОВИМА}

Карбокситерапија је терапијски поступак примене угљен-диоксида. Овај поступак познат је још од 1932. године када се почео примењивати у француском лечилишту Royat употребом термалне воде богате $\mathrm{CO}_{2}$ у виду гаса. Основна индикација примене гаса биле су болести периферног артеријског система, а због познатог учинка $\mathrm{CO}_{2}$ на вазодилатацију и побољшање микроциркулације. Током терапија уочило и мноштво других повољних учинака на поткожно ткиво и кожу која је постајала мекша, глађа и еластичнија. ${ }^{(30)}$

Bock и сарадници су у свом истраживању доказали да третирањем коже која је оштећена детерџентом, водом обогаћеном $\mathrm{CO}_{2}$ настаје побољшање регенерације коже, синтезе епидермалних липида и поправке кожне баријере. ${ }^{(31)}$ 
Данас се примена минералних вода богатих угљен-диоксидом користи у лечењу хроничних екцема, торпидних рана и трофичких улцерација код траума, опекотина и промрзлина. ${ }^{(1)}$

\section{УДРУЖЕНО ДЕЈСТВО БАЛНЕОКЛИМАТСКИХ ЧИНИЛАЦА У ДЕРМАТОЛОГИЈИ}

Море и сунце користе се већ хиљадама годинама у лечењу различитих болести. Већ је Хипократ описао позитиван утицај морске воде и сунчевог светла на стање организма. Одређени елементи у трагу, као што су магнезијум, калијум, натријум, те калцијум сулфат, присутни у морској води, апсорбују се кроз кожу и доприносе добром терапијском одговору на хелиоталасотерапију.

Од давнина је познато да хелиомаринотерапија, тј. третман са морском водом и сунцем, има благотворно дејство на кожне болести, посебно на псоријазу. Терапијски учинак се постиже комбинованим деловањем сунчевог светла, морске воде и свежег ваздуха.

Дерматовенеролог прим. др Даниел Живковић објавио је резултате десетогодишњег лечења 1.450 псоријатичних болесника хелиомаринотерапијом у Велому Лошињу (Хрватска). Од укупнога броја болесника, 710 је у овом лечилишту боравило три недеље, 580 четири недеље, а 160 више од четири недеље. Код већине псоријатичних болесника - 1.144 (72\%) учинак лечења трајао од четири до осам месеци, након чега се стање коже погоршавало. У 246 $(17 \%)$ болесника период опоравка без кожних промена је мање од четири месеца. ${ }^{(32)}$

Пример места где балнеотерапија доприноси лечењу многих болести и стања, посебно псоријазе, јесте Мртво море у Израелу. Налази се у јужном делу земље на око $400 \mathrm{~m}$ испод нивоа мора и највеће је светско хиперслано језеро. Познато је по својим балнеолошким и климатолош- ким својствима, посебно за лечење болести дерматолошког и реуматолошког порекла.

Због високог салинитета (море је најсланије на свету), вода је веома густа и дављења се никада не дешавају. У поређењу са океаном, Мртво море је богатије у садржају калцијума, магнезијума, калијума, и бромида, и има нижи садржај натријума, сулфата, и карбоната. Посебна комбинација ових минерала помаже да се ублаже свраб и иритација изазвани кожним болестима, као што су екцем и псоријаза.

Још један минералима богат балнеоклиматолошки чинилац Мртвог мора је његово „црно блато“, познато и као „битуменозни катран“. Терапијски ефекат прерађеног блата доводи се у везу са високим садржајем минерала, али и његовом способношћу да задржава топлоту и до неколико сати, стимулишући циркулацију крви и чишћење коже и отклањање мртвих епидермалних ћелија. Блато Мртвог мора је богат извор минерала. Идентификован је 21 минерал, од којих се 12 не налази ни у једном другом мору или океану. Главни минерали су магнезијум, калијум, фосфор, стронцијум, бром, сумпор, флуор, литијум, калцијум, хлор, натријум, јод, цинк и гвожђе. Концентрација брома је 50 пута већа, а бром је познат по својим умирујућем и опуштајућем ефекту. Он је и природни антибиотик, делује противупално и стога је користан у различитим инфламаторним и сувим дерматозама, као и код псоријазе, екцема и Ichthiosae.

Густа измаглица изнад Мртвог мора је, такође, богата минералима. Удисање бромида, који су јаки седативи, делује умирујуће код оболелих од псоријазе, и посебно је значајно међу онима чија је болест повезана са стресом. Бром улази у организам и унутрашње органе и кроз кожу, мада не тако ефикасно као када се удахне. ${ }^{(8)}$

Климатотерапија атопијског дерматитиса на Мртвом мору је веома ефикасан начин лечења ове болести, али захтева медицински надзор током целе дужине боравка пацијента. ${ }^{(33)}$ 


\section{ЗАКЉУЧАК}

Многобројни балнеолошки чиниоци са успехом се користе у дерматологији, као средства за негу коже, или улазе у састав козметичких препарата за негу коже.

Иако се неки балнеоклиматски фактори, као што су минералне воде богате сумпором, од давнина користе у лечењу инфекција коже, данас, када се говори о терапијској примени балнеоклиматских чинилаца, истиче се успех постигнут у лечењу псоријазе и атопијског дерматитиса.

Примена комбинованих балнеоклиматских чинилаца у лечењу кожних болести, у бањским и климатским лечилиштима Србије требало би да буде предмет даљих истраживања.

\section{ЛИТЕРАТУРА}

1. Јовановић Т. Балнеоклиматологија, CIBIF, Београд, 2002.

2. Ma'or Z., Henis Y., Alon Y., Orlov E., Sørensen KB, Oren A. Antimicrobial properties of Dead Sea black mineral mud. Int J Dermatol 2006; 45: 504-11.

3. Palmer R. In this our lightye and learned tyme: Italian baths in the era of the Renaissance. Med Hist Suppl 1990; 10: 14-22.

4. Lotti T., Ghersetich I. Le basi della dermocosmetologia termale. In: Caputo R, Monti M, eds. Manuale di Dermocosmetologia. Milan: Raffaello Cortina, 1995; 751-762.

5. Ghersetich I., Brazzini B., Hercogova J., Lotti TM. Mineral waters: instead of cosmetics or better than cosmetics? Clin Dermatol 2001; 19(4): 478-82.

6. Laquieze S., Czernielewski J., Baltas E. Beneficial use of Cetaphil moisturizing cream as part of a daily skin care regimen for individuals with rosacea. J Dermatolog Treat 2007; 18(3): 158-62.

7. Draelos ZD, Ertel KD, Berge CA. Facilitating facial retinization through barrier improvement. Cutis 2006; 78(4): 275-281.

8. Matz H., Orion E., Wolf R.

Balneotherapy in dermatology. Dermatol Ther 2003;16(2): 132-40.

9. Голушин 3., Јовановић М., Магда Н., Стојановић С., Матић М., Петровић
A. Effects of Rusanda Spa balneotherapy combined with calcipotriol on plaque psoriasis. Војносанитетски преглед 2015; 72(11): 1010-1017.

10. Nasermoaddeli A., Kagamimori S. Balneotherapy in medicine: a review. Environmental Health and Preventive Medicine 2005; 10(4): 171-179.

11. Паравина М., Степановић М., Рацић

$\Gamma$. Balneotherapy effectively acts on symptoms of psoriasis vulgaris. CEDVA Bull 2002; 4: 70-2.

12. Parish LC, Witkowski JA. Dermatologic balneology: the American view of waters, spas, and hot springs. J Eur Acad Dermatol Venereol 1994; 3: 465-467.

13. Nunes S., Tamura BM. A historical review of mineral water. Surg Cosmet Dermatol 2012; 4: 252-258.

14. Moufarrij S., Deghayli L., Raffoul W., Hirt-Burri N., Michetti M., de Buys Roessingh A., Norberg M., Applegate LA. How important is hydrotherapy? Effects of dynamic action of hot spring water as a rehabilitative treatment for burn patients in Switzerland. Annals of burns and fire disasters. 2014; 27(4): 184-191.

15. Tsai TF, Maibach HI. How irritant is water? An overview. Contact Dermatitis 1999; 41: 311-314.

16. Noo Ri Lee, Hae-Jin Lee, Na Young Yoon, Donghye Kim, Minyoung Jung, Eung Ho Choi. Acidic Water Bathing Could Be a Safe and Effective Therapeutic Modality for 
Severe and Refractory Atopic Dermatitis. Ann Dermatol 2016; 28(1): 126-129.

17. Carretero MI, Pozo M. Clay and non-clay minerals in the pharmaceutical industry: Part I. Excipients and medical applications. Applied Clay Science. 2009 Sep 30; 46(1): 73-80.

18. Clijsen R., Taeymans J., Duquet W., Barel A., Clarys P. Changes of skin characteristics during and after local Parafango therapy as used in physiotherapy. Skin Research and Technology 2008; 14(2): 237-42.

19. Gomes CD, Silva JB. Minerals and clay minerals in medical geology. Applied Clay Science. 2007; 36(1): 4-21.

20. Carretero MI, Pozo M. Clay and non-clay minerals in the pharmaceutical and cosmetic industries Part II. Active ingredients. Applied Clay Science. 2010 Feb 28; 47(3): 171-81.

21. Yekeler M., Ulusoy U., Hiçyılmaz C. Effect of particle shape and roughness of talc mineral ground by different mills on the wettability and floatability. Powder Technology 2004; 140(1): 68-78.

22. Потпара 3Р, Вучуровић СР, Марстијеповић НЂ, Бојовић ДР. Састав минералног блата - пелоида из Улцињске солане. Медицински часопис 2011; 45(1): $13-15$.

23. Andreassi L., Flori L. Mineral water and spas in Italy. Clin dermatol 1996: 14: 627-32.

24. Carabelli A., De Bernardi di Valserra G., De Bernardi di Valserra M., Tripodi S., Bellotti E., Pozzi R., Campiglia C., Arcangeli P. Effect of thermal mud baths on normal, dry and seborrheic skin. Clin Ter 1998; 149(4): 271-275.
25. Moraes JDD, Bertolino SRA, Cuffini SL, Ducart DF, Bretzke PE, Leonardi GR. Clay minerals: Properties and applications to dermocosmetic products and perspectives of natural raw materials for therapeutic purposes-A review. Int J Pharm 2017; 534(1-2): 213-219.

26. Tsankov N. High mountain climatotherapy. Clin Dermatol 1998; 16: 699-707.

27. Vocks E. Climatotherapy in atopic eczema. Handbook of Atopic Eczema. 2006; 507-23.

28. Karppinen TT, Ylianttila L, Kautiainen H, Reunala T, Snellman E. Empowering heliotherapy improves clinical outcome and quality of life of psoriasis and atopic dermatitis patients. Acta Derm Venereol 2015; 95: 579-582.

29. Seidl V., Hristakieva E., Harari M. Klimatherapie der Vitiligo am Toten Meer. Der Deutsche Dermatologe 1994; 2: 144-59.

30. Koutna N. Carboxytherapy - new, noninvasive method of aesthetic medicine. Cas Lek Cesk 2006; 145: 841-3.

31. Bock M., Schürer NY, Schwanitz HJ. Effects of CO2-enriched water on barrier recovery. Arch Dermatol Res 2004; 296(4): $163-8$

32. Стасић А., Батинац Т., Комадина C. Heliomarinotherapy in psoriasis. Acta Dermatovenerol Crоат 2004; 12(1): 51-4.

33. Harari M., Shani J., Seidl V., Hristakieva

E. Climatotherapy of atopic dermatitis at the Dead Sea: demographic evaluation and cost-effectiveness. Int J Dermatol 2000; 39(1): 59-69.

Контакт: Доц. др Констанса Лазаревић, Департман за биомедицинске науке, Државни универзитет у Новом Пазару, Вука Караџића бб, 36300 Нови Пазар, Србија, тел. 06414093 76, e-mail: konstansalazarevic@gmail.com

Доц. др Констанса Лазаревић, 1971. год. 